\title{
Structural and Microstructural Properties of Systems Based on $\mathrm{Bi}_{0.5} \mathrm{Na}_{0.5} \mathrm{TiO}_{3}$
}

\author{
Marcela ReVElo-CASTRO ${ }^{1}$ \\ SONIA GAONA-JURADO ${ }^{1}$ \\ Claudia Fernanda Villaquirán-Raigoza ${ }^{1}$
}

\section{Abstract}

Perovskites based on bismuth sodium titanates, $\mathrm{Bi}_{0.5} \mathrm{Na}_{0.5} \mathrm{TiO}_{3}$ (BNT), are incorporated into lead-free piezoelectric materials. Although BNT was discovered five decades ago, many aspects such as the structural complexity and the modifications produced when it is combined with other perovskites are not clearly understood. We studied the structural and microstructural properties of $\mathrm{BNT}$ upon addition of $\mathrm{BaTiO}_{3}(\mathrm{BT})$ and $\mathrm{SrTiO}_{3}(\mathrm{ST})$ during sol-gel synthesis. We characterized the ceramic powders by infrared and Raman spectroscopy, X-ray diffraction and scanning electronic microscopy. The addition of BT/ST modified the bonds, generating coexistence and phase transition and confirmed the existence of a morphotropic phase boundary.

Keywords: Sol-gel processes, BNT, Morphotropic Phase Boundary, Spectroscopy, Raman spectroscopy, Rietveld.

\section{Propiedades Estructurales y Microestructurales de Sistemas Basados en $\mathrm{Bi}_{0.5} \mathrm{Na}_{0.5} \mathrm{TiO}_{3}$}

\section{Resumen}

Las perovskitas basadas en titanato de bismuto y sodio, $\mathrm{Bi}_{0.5} \mathrm{Na}_{0.5} \mathrm{TiO}_{3}(\mathrm{BNT})$, son implementadas en materiales piezoeléctricos libres de plomo. A pesar de que el BNT fue descubierto hace cinco décadas, no se tiene aún claridad en ciertos temas cruciales como su complejidad estructural y las modificaciones que experimenta cuando se combina con otras perovskitas. En este trabajo se estudió la influencia de la adición de $\mathrm{BaTiO}_{3}(\mathrm{BT})$ y $\mathrm{SrTiO}_{3}(\mathrm{ST})$ sobre las propiedades

1 Grupo de Ciencia y Tecnología de Materiales Cerámicos (CYTEMAC), Universidad del Cauca. Popayán, Colombia.

Autor de correspondencia: Villaquirán-Raigoza, C.F. (Claudia Fernanda): Universidad del Cauca, Grupo de Ciencia y Tecnología de Materiales Cerámicos (CYTEMAC), Popayán, Colombia, Carrera 2 No 18N-61. Casa 17, Teléfono: $+57(2)$ 8209800, Correo electrónico: gure@unicauca.edu.co
Historia del artículo:

Artículo recibido: 14-X-2019/ Aprobado: 15-I-2020

Disponible online: 15 de enero de 2020

Discusión abierta hasta septiembre de 2021 
estructurales y microestructurales del $\mathrm{Bi}_{0.5} \mathrm{Na}_{0.5} \mathrm{TiO}_{3}(\mathrm{BNT})$, usando sol gel como método de síntesis. La caracterización de los polvos cerámicos se realizó por espectroscopia infrarroja y Ramman, difracción de rayos-Xy Microscopía electrónica de barrido, lo que permitió concluir que la adición de BT/ST modifica los enlaces, genera coexistencia y transición de fase y confirma la existencia de un contorno de fase morfotrópico.

Palabras Clave: Método Sol-gel, BNT, Contorno de Fase morfotrópico, Espectroscopía, Espectroscopía Raman, Rietveld.

\section{Propriedades estruturais e microestruturais de sistemas baseados em $\mathrm{Bi}_{0.5} \mathrm{Na}_{0.5} \mathrm{TiO}_{3}$}

\section{Resumo}

Perovskitas à base de titanatos de sódio de bismuto, $\mathrm{Bi}_{0.5} \mathrm{Na}_{0.5} \mathrm{TiO}_{3}(\mathrm{BNT})$, são incorporadas em materiais piezoelétricos sem chumbo. Embora o BNT tenha sido descoberto há cinco décadas, muitos aspectos como a complexidade estrutural e as modificações produzidas quando combinados com outros perovskitas não são claramente entendidos. Estudamos as propriedades estruturais e microestruturais do BNT após a adição de $\mathrm{BaTiO}_{3}$ (BT) e $\mathrm{SrTiO}_{3}$ (ST) durante a síntese sol-gel. Caracterizamos os pós cerâmicos por espectroscopia no infravermelho e Raman, difração de raios X e microscopia eletrônica de varredura. A adição de BT / ST modificou as ligações, gerando coexistência e transição de fase e confirmou a existência de um limite de fase morfotrópica.

Palavras chave: Processos Sol-gel, BNT, limite de fase morfotrópica, espectroscopia, espectroscopia Raman, Rietveld.

\section{Introduction}

The production of lead-free ferroelectric and piezoelectric materials has been investigated in recent years due to environmental concerns associated with the high toxicity of lead. A potential candidate is ferroelectric BNT and its solid solutions. Bismuth sodium titanate, $\mathrm{Bi}_{0.5} \mathrm{Na}_{0.5} \mathrm{TiO}_{3}$ (BNT) is a distorted perovskite with rhombohedral structure and spatial group R3c at room temperature (Smolenskii, et al., 1961). It is a ferroelectric material with high coercivity $\left(\mathrm{E}_{\mathrm{c}}=73 \mathrm{kV} /\right.$ $\mathrm{cm})$ and appreciable remnant polarization $\left(\mathrm{P}_{\mathrm{r}}=38 \mathrm{C} /\right.$ $\mathrm{cm}^{2}$ ) (Parija et al., 2013); its ferroelectric behavior, relaxor type, is attributed to the disorder in the occupation of site A in the perosvskite structure (Pérez, 2016). Its piezoelectric response can be improved by creating a morphotropic phase boundary (MPB) with other perovskites. Specially, the formation of solid solutions $(1-x) \mathrm{Bi}_{0.5} \mathrm{Na}_{0.5} \mathrm{TiO}_{3}-x \mathrm{BaTiO}_{3}(\mathrm{BNT}-x \mathrm{BT})$ and $(1-y) \mathrm{Bi}_{0.5} \mathrm{Na}_{0.5} \mathrm{TiO}_{3}-y \mathrm{SrTiO}_{3}$ (BNT-yST) does not inhibit the relaxor ferroelectric behavior and creates an MPB between the rhombohedral and tetragonal phases (Ma- chado et al., 2017; Lee et al., 2002; Hiruma et al., 2008, Jo et al., 2012), which makes its application possible for energy storage devices.

Sol-gel is one of the most widely used synthesis methods to obtain ceramic powders (Brinker and Scherer, 1990). It produces pure materials with high degree of homogeneity, which is not always possible with traditional methods (Palacios-Santos, 2004). In this document, we report the synthesis of ceramic powders for $(1-x) \mathrm{Bi}_{0.5} \mathrm{Na}_{0.5} \mathrm{TiO}_{3}-x \mathrm{BaTiO}_{3}(x=0.03,0.06$, $0.09,0.12)$ and $(1-y) \mathrm{Bi}_{0.5} \mathrm{Na}_{0.5} \mathrm{TiO}_{3}-y \mathrm{SrTiO}_{3}(y=0.23,0.26$, 0.29 ) by sol-gel, confirming the structure of an MPB in the studied range.

\section{Experimental procedure}

For the synthesis of BNT- $x$ BT and BNT-yST systems, we used bismuth nitrate $\left(\mathrm{Bi}_{5} \mathrm{O}(\mathrm{OH})_{9}\left(\mathrm{NO}_{3}\right)_{4}\right.$, Merck, 99.0\%), sodium nitrate $\left(\mathrm{NaNO}_{3}\right.$, Merck, 99.5\%), barium nitrate $\left(\mathrm{Ba}\left(\mathrm{NO}_{3}\right)_{2}\right.$, Baker Analyzed, 99.8\%), Strontium nitrate $\left(\mathrm{Sr}\left(\mathrm{NO}_{3}\right)_{2}\right.$, Aldrich, 99.9\%), Titanium 
n-butoxide (TBT) (Ti(OBu) ${ }_{4}$, Alfa Aesar, 99.0\%) and ethanol (Merck, 99.5\%).

Initially, we dissolved the nitrates in acidified water (with nitric acid 2M) with constant mixing to guarantee dissolution. Simultaneously, we dissolved the titanium precursor in methanol and slowly added the previously described precursor mix. We mixed the solution at room temperature for two hours; after that, we aged the mixture at $110^{\circ} \mathrm{C}$ for 12 hours. We grinded the sample to obtain a finer powder which was calcined at $1000^{\circ} \mathrm{C}$ for 2 hours. We characterized the structure by transmittance infrared and Raman dispersion spectroscopy and x-ray diffraction. We collected infrared spectra with a Thermo Scientific Nicolet iS10 FT-IR. For the Raman dispersion spectra, we used a Raman EZRaman-N (Enwave Optronics) coupled to a Leica DM300 microscope with a $532 \mathrm{~nm}$ wavelength laser excitation source. Spectra were taken at $32 \%$ power with 10 seconds integration time per spectrum. Spectra were deconvoluted using Fityk 0.9.8 software, which allows qualitative and semi-quantitative analysis of the spectral bands (Wojdyr and Fityk, 2010). For x-ray characterization, we used a Bruker D8 Advance diffractometer with $\mathrm{CuK} \alpha$ radiation operating in a range 20: $20-60^{\circ}$, with $0.02^{\circ}$ step size and a 2 s step time. We used the Rietveld method with the GSAS program to analyze the diffractograms and to conclude about the effect of the addition of BT/ST on the BNT structure. Microstructural characteristics were determined by scanning electronic microscopy (SEM) using an EVO MA15, Carl Zeiss.

\section{Results and discussion}

Figure 1 shows the Raman spectra for BNT- $x$ BT and BNT-yST, in the 100 a $1000 \mathrm{~cm}^{-1}$ range. The BNT spectrum (Figure 1 for $x=0, y=0$ ) presents five vibration bands centered at $131,270,520,575$ and $842 \mathrm{~cm}^{-1}$, which agrees with reports by other researchers (Lidjici, et al., 2015; Siny et al., 2000). The first band at $\sim 131 \mathrm{~cm}^{-1}$ is attributed to Na-O bond vibration. The second band, located at $270 \mathrm{~cm}^{-1}$, is associated to the $\mathrm{TiO}_{6}$ group vibration observed in the perovskites (Trujillo et al., 2005), while the bands at 520 and $575 \mathrm{~cm}^{-1}$ are associated with vibrations involving oxygen shifts. Finally, the band at $842 \mathrm{~cm}^{-1}$ can be attributed to oxygen vacancies (Zannen, et al., 2012; Selvamani, et al., 2011). Upon addition of BT
(Figure 1a), the first band $\left(\sim 131 \mathrm{~cm}^{-1}\right)$ shifts towards lower frequencies and decreases in intensity until disappearing for $x=0.09$. The changes in position and form are more prominent in the bands attributed to the $\mathrm{Na} / \mathrm{Ba}-\mathrm{O}$ vibration; the $131 \mathrm{~cm}^{-1}$ band shift results from Ba having a higher mass compared to Na (Suchanicz, JankowskaSumara and Kruzina, 2011; Buixaderas et al., 2007; Rout et al., 2005; Kreisel et al.; 2000), and the broadening and pronounced decrease in intensity are related to the A-O bond weakening (Shi et al, 2014).

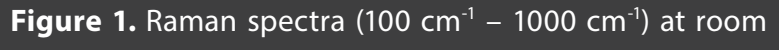
temperature for ceramic powders (a) BNT-xBT (b) BNT-yST
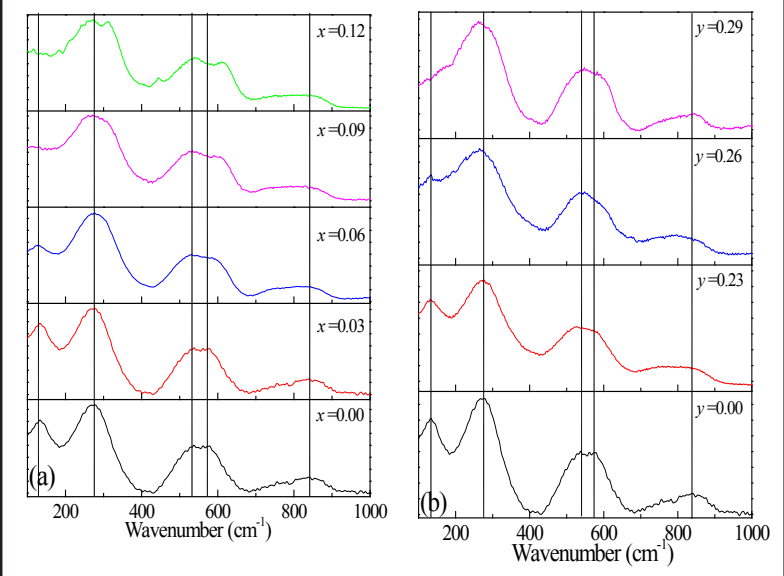

The band at $270 \mathrm{~cm}^{-1}$, associated to the Ti- 0 bond, splits after BT addition, which reveals a symmetry change to one whose irreducible representation has a higher number of active Raman bands; i.e., the rhombohedral and tetragonal phases coexist [32]. This is confirmed by the appearance of a band at $\sim 310 \mathrm{~cm}^{-1}$, which corresponds to a tetragonal symmetry [28]. The bands at $520 \mathrm{~cm}^{-1}$ and $575 \mathrm{~cm}^{-1}$ are more sensitive to structural changes, according to studies in other type of materials with perovskite structure [28]. High frequency Raman bands are usually caused by alteration of the oxygen ion concentration as the valence difference between the ions in the host lattice and the dopant can produce oxygen vacancies. $[26,31]$. There are interesting changes in several regions, especially the band at $520 \mathrm{~cm}^{-1}(x=0.00)$ which shifts to $544 \mathrm{~cm}^{-1}$ and the band at $575 \mathrm{~cm}^{-1}$ which shifts to $620 \mathrm{~cm}^{-1}$, both for $x=0.12$. This behavior is related to the symmetry change due to phase transition (rhombohedral/tetragonal). Researchers have reported that in the BNT-yST system 
with $0.10 \leq y \leq 0.30$, the rhombohedral (R3c) and tetragonal (P4mm) phases coexist (Kim etal., 2017), while for higher concentrations the tetragonal and pseudo cubic phases, characteristic of ST, coexist (Parija et al., 2012). The main characteristics of the Raman spectra for the BNT-yST system in Figure 1b, are: (i) bands at $\sim 136 \mathrm{~cm}^{-1}, \sim 276 \mathrm{~cm}^{-1}$ and $\sim 548 \mathrm{~cm}^{-1}$ and some wider and lower intensity bands between $700 \mathrm{~cm}^{-1}$ and 900 $\mathrm{cm}^{-1}$; (ii) broadening of the band at $\sim 276 \mathrm{~cm}^{-1}$ for $y=0.26$ and $y=0.29$; (iii) shifting and splitting of the band at $\sim 548 \mathrm{~cm}^{-1}$. Band splitting and frequency variations are characteristic of a local structural reorder. The bands at $\sim 136 \mathrm{~cm}^{-1}$ can be assigned to the vibrations of site A cations. Figure 2a shows the x-ray diffraction pattern corresponding to the BNT sample. The system crystalizes as $\mathrm{Bi}_{0.5} \mathrm{Na}_{0.5} \mathrm{TiO}_{3}$ with rhombohedral symmetry and spatial group R3 according to the CIF (Crystallographic Information File) number 2103295 (Jones and Thomas, 2002), as indicated by the Rietveld refinement shown in Figure 2b.

Figure 3 shows the BNT- $x \mathrm{BT}$ and BNT- $y$ ST system diffraction patterns, with all characteristic peaks from BNT and without secondary phases, which indicates that BT/ST diffuses through the BNT lattice forming a solid solution. Zooming in different areas of the diffractogram in Figure 3a, shows the changes in the shape of peaks (111) (Figure 4a) and (202) (Figure 4b) for BNT. There is a displacement towards lower $2 \theta$ as the concentration of BT increases, which indicates a modification in the lattice structure parameters, confirming the analysis done by Raman.

\section{Figure 2. (a) XRD patterns of BNT system; (b) Rietveld refinement using GSAS program}
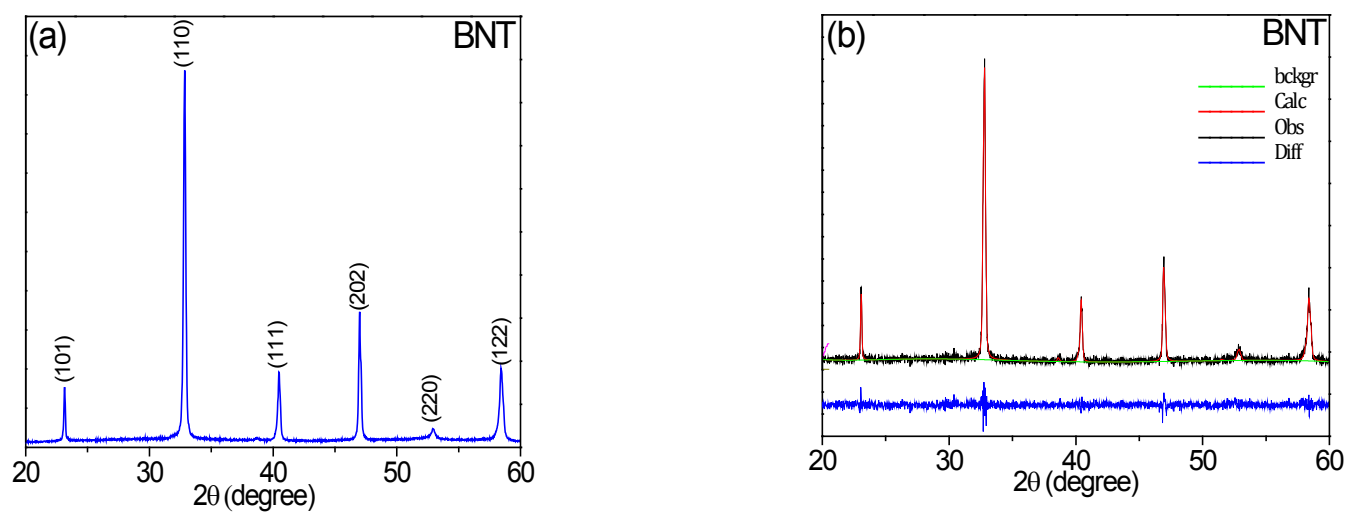

Figure 3. XRD patterns for (a) BNT-xBT; (b) BNT-yST
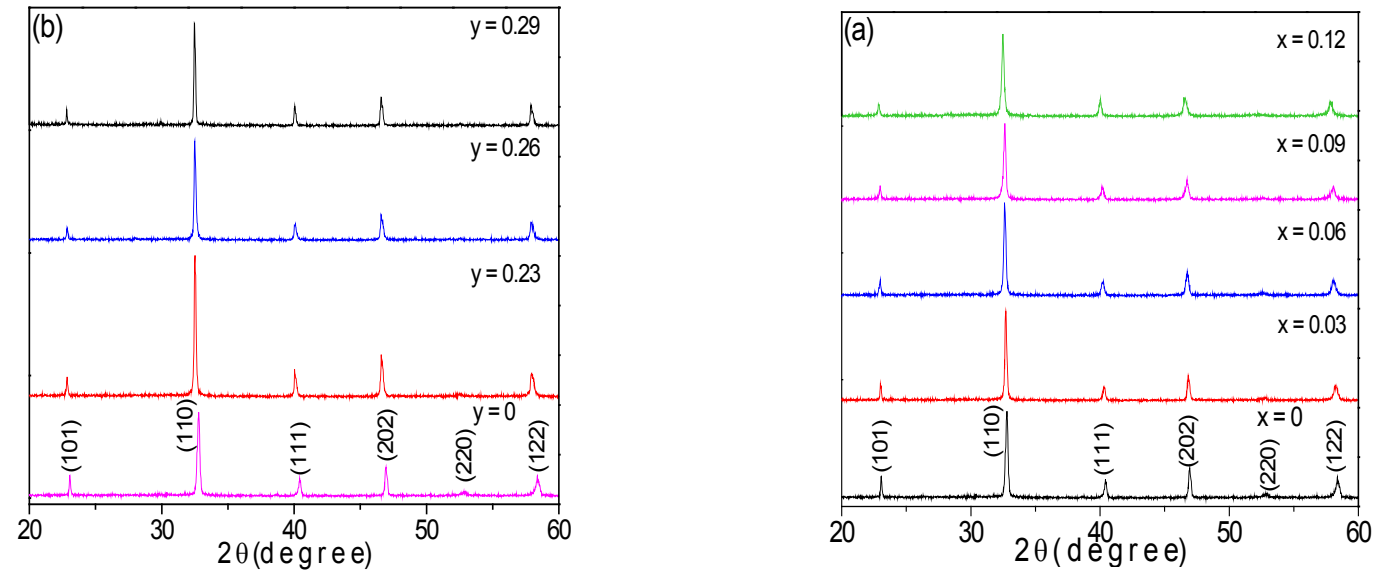
Figure 4. $2 \theta$ ranges for the BNT- $x$ BT XRD patterns between (a) $39^{\circ}-41^{\circ}(111)$ and (b) $46^{\circ}-47.5^{\circ}(202)$

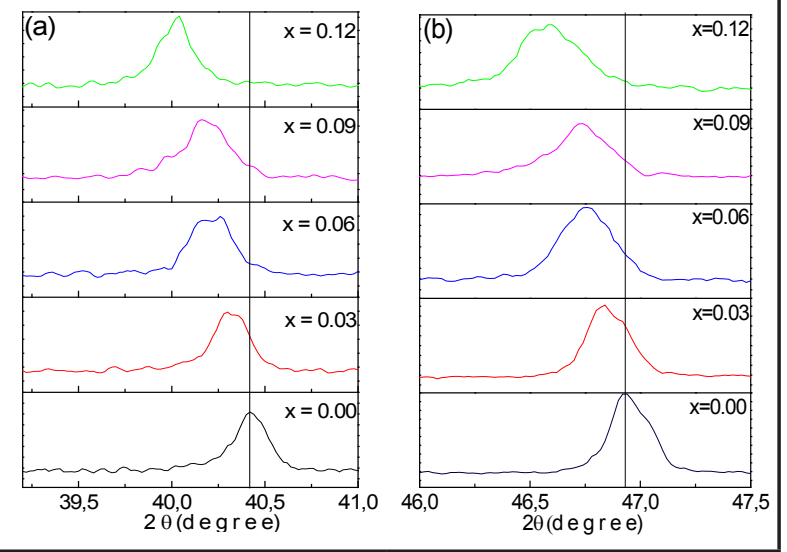

Figure 5. $2 \theta$ range (a) $39-41^{\circ}(111)$ and (b) $46-47.5^{\circ}$ (202) from the BNT-yST

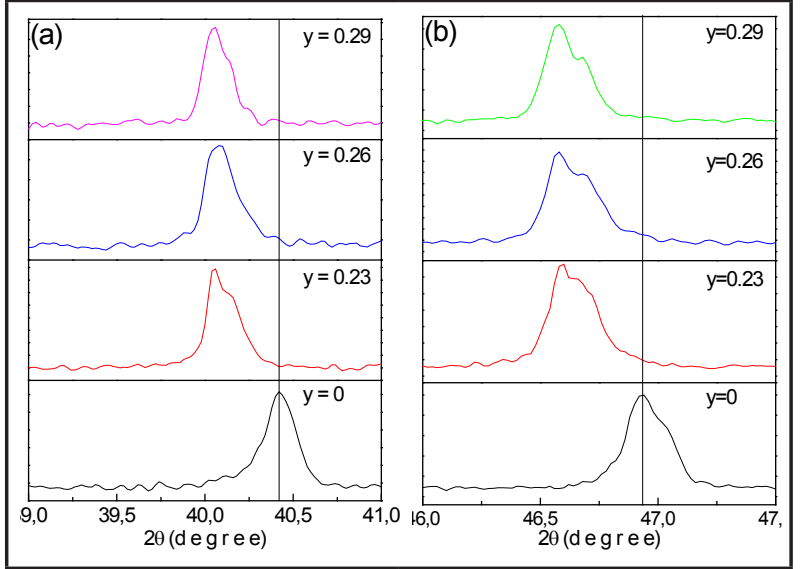

The evolution of the peaks corresponding to the (111) y (202) lattice planes confirms not only the rhombohedral structure characteristic of BNT but also the coexistence of the rhombohedral and tetragonal phases characteristic of BT; i.e. as shown in Figure 4, for $\mathrm{x}=0.03$, there is an overlap of two peaks, interpreted as the coexistence of two phases. This overlap evolves with the increase in BT and for $x=0.12$ the system has a tetragonal phase; that is, there is two-phase coexistence for $0.03 \leq x<0.12$. The coexistence of phases is more noticeable in Figure $\mathbf{3 b}$ diffractograms (BNT-yST), observed in the same peaks (Figure 5); an increase in ST shifts the diffraction signals to lower angles, which corresponds to an increase in the lattice parameters. For $y=0.23$, a split in the peak between $46^{\circ}-47.5^{\circ}$ forms an additional shoulder; for higher compositions the two shoulders converge, which can be interpreted as a new phase transition. The results suggest that the rhombohedral and tetragonal phases are present in the BNT-yST system for ST concentrations $0.23 \leq y \leq 0.29$; therefore, the solid solution also presents an MPB.

To supplement the XRD analysis, we applied Rietveld refinement to all diffractograms and the results are shown in Tables 1-2 for BNT- $x$ BT and BNT$y \mathrm{ST}$, respectively. As an example, Figure $\mathbf{6}$ shows the adjustments for the diffractograms corresponding to $x=0.03$ BT, $x=0.12$ BT, $y=0.23$ ST and $y=0.29$ ST.

Figure 6. Rietveld refinement for the BNT-xBT and BNT-yST using GSAS program for the following molar concentrations: (a) $x=0.03 \mathrm{BT}$, (b) $\mathrm{x}=0.12 \mathrm{BT}$, (c) $y=0.23 \mathrm{ST}$ and (d) $y=0.29 \mathrm{ST}$

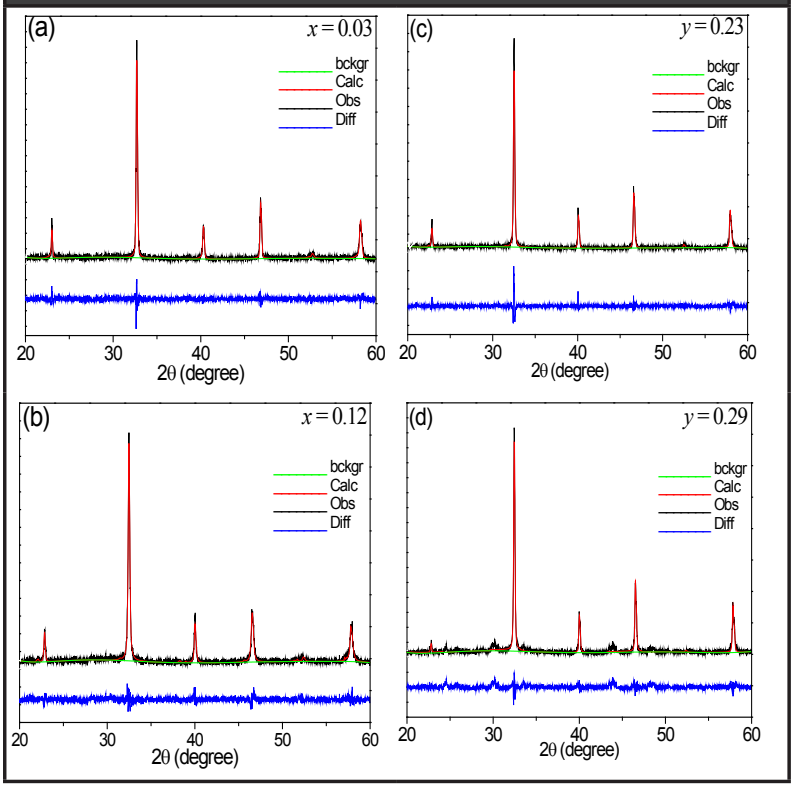

The data reported in Tables 1 and $\mathbf{2}$ confirm the discussion already made based on raman spectroscopy and XRD patterns. The tables show that the volume modification does not follow a linear behavior, suggesting that even if BT/ST is completely soluble in the BNT matrix, the addition generates distortion in the structure (originally rhombohedral) due to variation in the size of the ions. To have a clear idea of the effect of the dopant size on the crystal structure, we analyzed the tolerance factor, $t$, proposed by Goldschmidt, which quantifies the degree of distortion of the perovskite in terms of ionic packing (Bhalla, Guo and Roy, 2000). For an ideal perovskite, (structure without distortions) $t=1$. If ion $A$ radius is smaller than the ideal value, $t$ is less than 1 ; therefore, when $t$ decreases, the symmetry of the crystal is reduced. 
TABLE 1. LATTICE AND PHASE PARAMETERS OBTAINED FROM RIETVELD REFINEMENT ADJUSTMENTS FOR THE BNT-XBT SYSTEM USING GSAS PROGRAM

\begin{tabular}{|c|c|c|c|c|c|c|}
\hline \multirow{2}{*}{\multicolumn{2}{|c|}{$\begin{array}{c}\text { Refined parameter } \\
\qquad x=0.00\end{array}$}} & \multicolumn{5}{|c|}{$(1-x) B_{0.5} \mathrm{Na}_{0.5} \mathrm{TiO}_{3}-\mathrm{xBaTiO}$} \\
\hline & & $x=0.03$ & $x=0.06$ & $x=0.09$ & $x=0.12$ & \\
\hline \multirow{3}{*}{ Phase $1 \mathrm{P} 4 \mathrm{~mm}$} & $a(\AA)$ & - & 3.886 & 3.997 & 3.930 & 3.567 \\
\hline & $b(\AA)$ & - & 3.886 & 3.997 & 3.930 & 3.567 \\
\hline & $c(\AA)$ & - & 3.915 & 3.998 & 3.882 & 3.593 \\
\hline \multicolumn{2}{|c|}{ Volume $\left(\AA^{3}\right)$} & - & 59.106 & 63.863 & 59.937 & 45.711 \\
\hline \multirow{3}{*}{ Phase 2 R3c } & $a(\AA)$ & 5.470 & 5.490 & 5.511 & 5.531 & - \\
\hline & $b(\AA)$ & 5.470 & 5.490 & 5.511 & 5.531 & - \\
\hline & $c(\AA)$ & 13.459 & 13.478 & 13.516 & 13.529 & - \\
\hline \multicolumn{2}{|c|}{ Volume R3c $\left(\AA^{3}\right)$} & 348.721 & 351.707 & 355.440 & 358.417 & - \\
\hline \multicolumn{2}{|c|}{$x^{2}$} & 1.185 & 1.152 & 1.085 & 1.130 & 1.231 \\
\hline
\end{tabular}

TABLE 2. LATTICE AND PHASE PARAMETERS OBTAINED FROM RIETVELD REFINEMENT ADJUSTMENTS FOR THE (1-Y) $\mathrm{BI}_{0.5} \mathrm{NA}_{0.5} \mathrm{TIO}_{3}-Y_{\text {SRTIO }}$ SYNTHESIZED BY SOL GEL, USING THE GSAS PROGRAM

\begin{tabular}{|c|c|c|c|c|c|}
\hline \multirow{2}{*}{\multicolumn{2}{|c|}{$\begin{array}{l}\text { Refined parameter } \\
\qquad y=0.00\end{array}$}} & \multicolumn{4}{|c|}{$(1-y) \mathrm{Bi}_{0.5} \mathrm{Na}_{0.5} \mathrm{TiO}_{3}-y \mathrm{SrTiO}_{3}$} \\
\hline & & $y=0.23$ & $y=0.26$ & $y=0.29$ & \\
\hline \multirow{3}{*}{ Phase $1 \mathrm{P} 4 \mathrm{~mm}$} & $a(\AA)$ & - & 3.996 & 3.984 & 3.988 \\
\hline & $b(\AA)$ & - & 3.996 & 3.984 & 3.988 \\
\hline & $c(\AA)$ & - & 4.081 & 3.986 & 4.036 \\
\hline \multicolumn{2}{|c|}{ Volume P4mm $\left(\AA^{3}\right)$} & - & 65.174 & 63.259 & 64.183 \\
\hline \multirow{3}{*}{ Phase 2 R3c } & $a(\AA)$ & 5.470 & 5.515 & 5.491 & - \\
\hline & $b(\AA)$ & 5.470 & 5.515 & 5.491 & - \\
\hline & $c(\AA)$ & 13.459 & 13.509 & 13.479 & - \\
\hline \multicolumn{2}{|c|}{ Volume $R 3 c\left(\AA^{3}\right)$} & 348.721 & 355.851 & 352.006 & - \\
\hline \multicolumn{2}{|c|}{$x^{2}$} & 1.185 & 1.275 & 1.150 & 1.092 \\
\hline
\end{tabular}

Figure 7. Variation of the tolerance factor with the percentage of (a) BNT- xBT and (b) BNT- yST
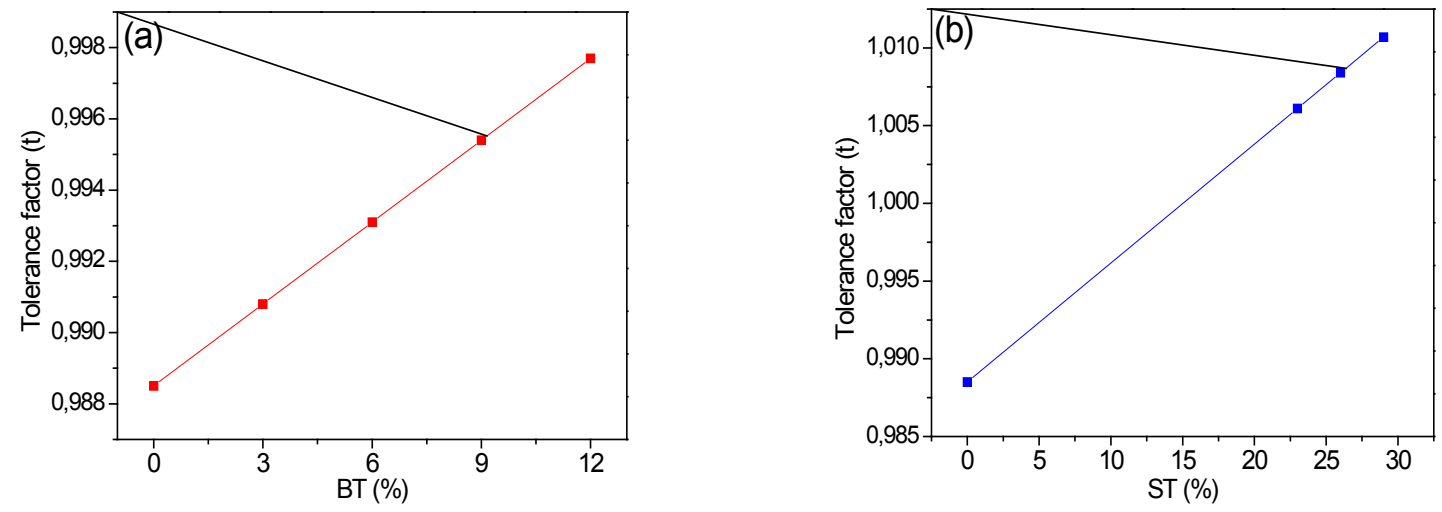


\section{Figure 8. SEM micrograph for (a) BNT, (b) $x=0.06 \mathrm{BT}$, (c) $y=0.23 \mathrm{ST}$}

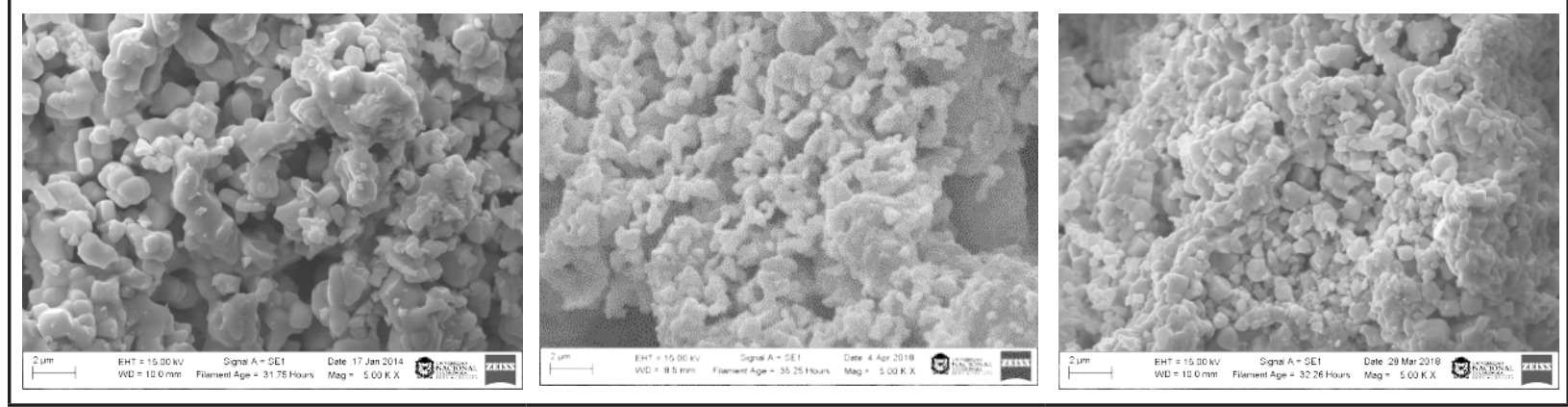

Figure 7 shows that the tolerance factor increases linearly with the BT/ST concentration. While BNT $t=0.988$, BNT-0.29ST, $t=1.013$, which indicates that BNT's rhombohedral structure becomes more symmetrical. However, because the perovskites are not entirely ionic compounds, the tolerance factor only gives an estimated approximation of the crystal structure.

Figure 8 shows the micrographs for BNT and the BNT- $x$ BT and BNT- $y$ ST system with concentrations $x=0.06$ and $y=0.23$. The SEM microscopy only allows us to observe an effect of the addition of BT / ST on the particular size. The particles have a size distribution between 1 and $2 \mu \mathrm{m}$, but there are also some smaller particles. This size distribution can be the result of a pre-sintering process at the calcination temperature. The particles have an irregular shape and the particle size decreases and becomes more uniform with the inclusion of BT/ST.

\section{Conclusions}

We obtained monophasic ceramic powders with a perovskite structure for all the synthesized compositions. The percentages of BT/ST added to the BNT matrix were completely soluble in the matrix, maintaining the monophasic perovskite structure; however, there was a variation in the lattice parameters, modifying the phase percentage (rhombohedral-tetragonal) as the concentration increased. The coexistence of the rhombohedral (BNT) and the tetragonal (BT/ST) phases was confirmed by X-ray diffraction and Rietveld refinement, which indicated the generation of a morphotropic phase boundary in the obtained solid solutions.

\section{Acknowledgment}

The author acknowledges the financial support from Universidad del Cauca.

\section{References}

Bhalla A. S., Guo R., Roy R. (2000). The perovskite structure-a review of its role in ceramic science and technology, Mater. Res. Innov. 4 3-26. doi: 10.1007/ s100190000062.

Brinker C. J., Scherer G. W. (1990). Sol-gel science: the physics and chemistry of sol-gel processing, Academic, Inc., New York.

Buixaderas E., Kamba S., Petzelt J., Drahokoupil J., Laufek F., Kosec M. (2007). Dielectric anisotropy in relaxor ferroelectric $\mathrm{Pb}_{0.775} \mathrm{La}_{0.15}\left(\mathrm{Zr}_{0.4} \mathrm{Ti}_{0.6}\right) \mathrm{O}_{3}$ ceramics, Appl. Phys. Lett. 91, 112909. doi: 10.1063/1.2783962.

Hiruma Y., Imai Y., Watanabe Y., Nagata H., Takenaka T. (2008). Large electrostrain near the phase transition temperatura of $\left(\mathrm{Bi}_{0.5} \mathrm{Na}_{0.5}\right) \mathrm{TiO}_{3}-\mathrm{SrTiO}_{3}$ ferroelectric ceramics, Appl. Phys. Lett. 92 262904. doi: 10.1063/1.2955533.

Jo W., Dittmer R., Acosta M., Zang J., Groh C., Sapper E., Wang K., Rödel J. (2012). Giant electric-field-induced strains in lead-free ceramics for actuator applications-status and perspective, J. Electroceramics, 29 71-93. doi: 10.1007/s10832-012-9742-3.

Jones G. O., Thomas P. A. (2002). Investigation of the structure and phase transitions in the novel Asite substituted distorted perovskite compound $\mathrm{Na}_{0.5} \mathrm{Bi}_{0.5} \mathrm{TiO}_{3}$, Acta Cryst. B. 58 168-178. doi: 10.1107/ S0108768101020845.

Kreisel J., Glazer A. M., Jones G., Thomas P. A. Abello V., Lucazeau G. (2000). An x-ray diffraction and Raman spectroscopy investigation of A-site substituted perovskite compounds: the $\left(\mathrm{Na}_{1-x} \mathrm{~K}_{x}\right)_{0.5} \mathrm{Bi}_{0.5} \mathrm{TiO}_{3}(0 \leq x$ 
$\leq 1)$ solid solution, J. Phys.: Condens. Matter. 12,32673280. doi: 10.1088/0953-8984/12/14/305.

Kim S., Choi H., Han S., Park J. S., Lee M. H., Song T. K., Kim M.-H., Do D., Kim W.-J.(2017). A correlation between piezoelectric response and crystallographic structural parameter observed in lead-free $(1-\mathrm{x})\left(\mathrm{Bi}_{0.5} \mathrm{Na}_{0.5}\right)$ $\mathrm{TiO}_{3}-\mathrm{XSrTiO}_{3}$ piezoelectrics, J. Am. Ceram. Soc. 37(4), 1379-1386. doi:10.1016/j.jeurceramsoc.2016.11.023

Lee, J.-K.; Hong, K. S.; Kim, C. K.; Park, S.-E. (2002). Phase transitions and dielectric properties in $\mathrm{A}$-site ion substituted $\left(\mathrm{Na}_{1 / 2} \mathrm{Bi}_{1 / 2}\right) \mathrm{TiO}_{3}$ ceramics $(\mathrm{A}=\mathrm{Pb}$ and $\mathrm{Sr})$, Journal of Applied Physics, 91(7): 4538-4542. doi: 10.1016/j.jallcom.2016.08.116.

Lidjici H., Lagoun B., Berrahal M., Rguitti M., Hentatti M. A., Khemakhem H., XRD, Raman and electrical studies on the $(1-\mathrm{x})\left(\mathrm{Na}_{0.5} \mathrm{Bi}_{0.5}\right) \mathrm{TiO}_{3}-\mathrm{xBaTiO}{ }_{3}$ lead free ceramics, J. Alloys Compd. 618 (2015) 643-648. doi: 10.1016/j. jallcom.2014.08.161.

Machado R., Valdeci B., Ochoa D. A., Cerdeiras E., Mestres L., García J. E. (2017). Elastic, dielectric and electromechanical properties of $\left(\mathrm{Bi}_{0.5} \mathrm{Na}_{0.5}\right) \mathrm{TiO}_{3}-\mathrm{BaTiO}_{3}$ piezoceramics at the morphotropic phase boundary region, J. Alloys Compd. 690, 568-574.

Palacios-Santos L. A. (2004). Métodos de síntesis de nuevos materiales basados en metales de transición, Revista Facultad de Ingeniería, 32 51-61.

Parija B., Badapanda T., Panigrahi S., Sinha T. P. (2013). Ferroelectric and piezoelectric propieties of (1-x) $\left(\mathrm{Bi}_{0.5} \mathrm{Na}_{0.5}\right) \mathrm{TiO}_{3}-\mathrm{xBaTiO}{ }_{3}$ ceramics, J. Mater. Sci. Mater. Electron. 24 402-410. doi: 10.1007/s10854-0120764-z

Parija B., Rout S. K., Cavalcante L. S., Simões A. Z., Panigrahi S., Longo E., Batista N. C. (2012). Structure, microstructure and dielectric properties of $100-\mathrm{x}\left(\mathrm{Bi}_{0.5} \mathrm{Na}_{0.5}\right)$ $\mathrm{TiO}_{3}-\mathrm{x}\left[\mathrm{SrTiO}_{3}\right]$ composites ceramics, Appl. Phys. A. 109 715-723. doi: 10.1007/s00339-012-7105-1.

Perez M. C. (2016). Láminas delgadas de $\left(\mathrm{Bi}_{0.5} \mathrm{Na}_{0.5}\right)_{1}$. ${ }_{\mathrm{x}} \mathrm{Ba}_{\mathrm{x}} \mathrm{TiO}_{3}$ en torno a la frontera de fase morfotrópica preparadas por métodos de depósito químico y fotoquímico de disoluciones, Tesis doctoral, Universidad de Navarra, España.

Rout D., Subramanian V., Hariharan K., Murthy V. R. K., Sivasubramanian V. (2005). Raman spectroscopic study of $\left(\mathrm{Pb}_{1-\mathrm{x}} \mathrm{Ba}_{\mathrm{x}}\right)\left(\mathrm{Yb}_{1 / 2} \mathrm{Ta}_{1 / 2}\right) \mathrm{O}_{3}$ ceramics, J. Appl. Phys. 98, 103503-103503-6. doi: 10.1063/1.2131188.

Selvamani R., Singh G., Sathe V., Tiwari V. S., Gupta P. K. (2011). Dielectric, structural and Raman studies on $\left(\mathrm{Na}_{0.5} \mathrm{Bi}_{0.5} \mathrm{TiO}_{3}\right)_{(1-x)}\left(\mathrm{BiCrO}_{3}\right)_{x}$ ceramic, J. Phys.: Condens. Matter. 23 55901. doi: 10.1088/09538984/23/5/055901.
Shi J., Fan H., Liu X., Bell A. (2014). Large Electrostrictive Strain in $\left(\mathrm{Bi}_{0.5} \mathrm{Na}_{0.5}\right) \mathrm{TiO}_{3}-\mathrm{BaTiO}_{3}-\left(\mathrm{Sr}_{0.7} \mathrm{Bi}_{0.2}\right) \mathrm{TiO}_{3}$ Solid Solutions, J. Am. Ceram. Soc. 97, 848-853. doi: 10.1111/jace.12712.

Siny I. G., Husson E., Beny J. M., Lushnikov S. G., Rogacheva E. A., Syrnikov P. P. (2000). Raman scattering in the relaxor-type ferroelectric $\mathrm{Na}_{1 / 2} \mathrm{Bi}_{1 / 2} \mathrm{TiO}_{3}$, Ferroelectrics, 248 57-78. doi: 10.1080/00150190008223669.

Smolenskii G. A, Isupov A. I., Agranovskaya A: I., Krainik N. N. (1961). New ferroelectrics of complex composition, Soviet Physics-Solid State, 2 2651-2654.

Suchanicz J., Jankowska-Sumara I., Kruzina T. V. (2011). Raman and infrared spectroscopy of $\mathrm{Na}_{0.5} \mathrm{Bi}_{0.5} \mathrm{TiO}_{3}$. $\mathrm{BaTiO}_{3}$ ceramics, J. Electroceram. 27, 45-50. doi: 10.1007/s10832-011-9648-5.

Trujillo S., Kreisel J., Jiang Q., Smith J. H., Thomas P. A., Bouvier P., Weiss F. (2005). The high-pressure behavior of Ba-doped $\mathrm{Na}_{1 / 2} \mathrm{Bi}_{1 / 2} \mathrm{TiO}_{3}$ investigated by Raman spectroscopy, J. Phys. Condens. Matter. 17 6587-6597. doi: 10.1088/0953-8984/17/41/027.

Wojdyr M., Fityk (2010). a general-purpose peak fitting program, J. Appl. Crystallogr. 43 1126-1128. doi: 10.1107/S0021889810030499.

Zannen M., Lahmar A., Dietze M., Khemakhem H., Kabadou A., Es-Souni M. (2012). Structural, optical, and electrical properties of $\mathrm{Nd}$-doped $\mathrm{Na}_{0.5} \mathrm{Bi}_{0.5} \mathrm{TiO}_{3}$, Mater. Chem. Phys. 134, 829-833. doi: 10.1016/j.matchemphys.2012.03.076.

\section{PARA CITAR ESTE ARTÍCULO / TO REFERENCE THIS ARTICLE / PARA CITAR ESTE ARTIGO /}

Revelo-Castro, M.; Gaona-Jurado, S.; Villaquirán-Raigoza, C.F. (2020). Structural and Microstructural Properties of Systems Based on $\mathrm{Bi}_{0.5} \mathrm{Na}_{0.5} \mathrm{TiO}_{3}$. Revista EIA, 17(33) enero-junio, Reia33012 pág. 1-8. Disponible en: https:// doi.org/10.24050/reia.v17i33.1356 